\title{
Development of low sticky texture natto "MAMENOKA"
}

\author{
Yuji KuBo and Rikio NAKAgaWA*
}

[Translation from Synthesiology, Vol.11, No.1, p.1-11 (2018)]

\begin{abstract}
Many foreigners appreciate Japanese foods because of their health properties. However, few foreigners like natto, because of its sticky texture. The Ibaraki prefectural government started the "development of low sticky texture natto" project to export natto-based products to France and Germany, among other countries. The use of specially shaped packages, or edible glue lowers the stickiness of natto. However, these methods require new processing machines. Natto makers would like to produce low sticky texture natto without having to purchase new machines. To meet this challenge, we developed a new strain of bacteria from a natural mutation during subculture of Bacillus subtilis. This strain produces substances with less stickiness. We named this strain "IBARAKI lst-1," and called natto products

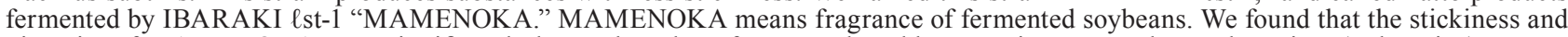
viscosity of MAMENOKA were significantly lower than that of commonly sold natto. Firmness, color, and nutrient (polyamine) content of MAMENOKA were almost the same as commonly sold natto. We performed taste tests of MAMENOKA and commonly sold natto. The majority of the people who tested MAMENOKA reported that it was easier to swallow than commonly sold natto, because of its low viscosity. Some natto makers in Ibaraki are utilizing these properties of MAMENOKA to develop new natto-based products, such as dipping sauces, pastes, and dressings.
\end{abstract}

Keywords : Natto, Bacillus subtilis, low sticky texture, IBARAKI $\ell$ st-1, MAMENOKA

\section{Introduction}

The domestic consumption of natto has leveled off due to the effect of reduced rice consumption, and the overheating price competition is causing pain to the small and medium-sized companies. Then, washoku or Japanese food was registered as a UNESCO Intangible Cultural Heritage in December 2013, and interest in Japanese food has increased worldwide.

However, the diffusion of natto overseas has not reached far, except in Asia, and there is plenty of room for opening foreign markets.

Against such a background, the development of natto for overseas market started in 2013 through the efforts of the "Ibaraki Council for the Promotion of Growing Industry" promoted by the Industrial Policy Division, Ibaraki prefectural government. The coordinator of the Council thought that the sticky texture of natto was a negative factor in promoting this product overseas where there was no culture of using chopsticks or practice of slurping food, and it was proposed that the stickiness of natto should be reduced. The idea was that natto with low stickiness might be readily accepted overseas.

It was assumed that rather than eating natto as it is, it would be promoted as an additive food ingredient for preparing menus. The characteristic of natto that it has "high percentage of protein and low fat in comparison to the calories" was expected to be the appeal point for healthconscious consumers.
The term "natto" generally refers to "sticky" or "stringy" natto. Therefore, in this paper, the sticky natto will be simply called "natto."

\section{Objective and the scenario to achieve the objective}

The objectives were to develop natto with low stickiness with the aim of selling natto as a new food ingredient overseas, and to diffuse the research results to natto manufacturing companies in Ibaraki Prefecture. The scenario to achieve these objectives was set in the order from (1) to (5) as follows:

(1) To clarify the necessary requirements to spread natto overseas

(2) To develop and breed natto bacteria needed for overseas deployment

(3) To conduct evaluation of characteristics of natto made from the newly bred natto bacteria

(4) To understand the characteristics of the newly developed natto and to publicize this product to related people

(5) To conduct activities needed for overseas diffusion including creation of menus for foreigners and participation in overseas food exhibitions

For (1), after discussions with the related parties, the requirements were set as development and branding of natto with low stickiness and proposal of natto menus that would be accepted by foreigners. For (2), literature search was conducted at the Industrial Technology Institute of Ibaraki Prefecture (Ibaraki ITI), and it was decided that selection and culture of natural mutant strains that are generated in the process of subculturing would be done.

Laboratory of Local Foods, Industrial Technology Institute Of Ibaraki Prefecture 3781-1 Nagaoka, Ibaraki Town, Higashi Ibaraki-Gun 311- 3195, Japan * E-mail: nakagawa@kougise.pref.ibaraki.jp

Original manuscript received July 26, 2017, Revisions received September 19, 2017, Accepted September 20, 2017 
For (3) to (4), it was decided that the stickiness, hardness, color, and nutrients of natto would be evaluated, and sensory evaluation would be conducted. For (5), through discussions with related parties as in (1), it was decided that a brand name and logo would be selected, creation of new menus using natto would be contracted to a western cuisine specialist, and participation in worldwide food exhibitions held in Europe would be promoted and so forth. (Fig. 1).

\section{Issues that had to be solved}

There are several methods proposed for the manufacture of natto with low stickiness, and the following have been publicized as patent information ${ }^{[1]-[3]}$ :

(1) Method by which the form of container is devised and natto is made by fermenting the soybean in the container

(2) Method of adding a glue ingredient in the natto manufacturing process

(3) Method of mixing cinnamon bark, cocoa, sugar, mayonnaise, and others to natto that uses okara (soy pulp) as its main ingredient.

The method for manufacturing natto with low stickiness

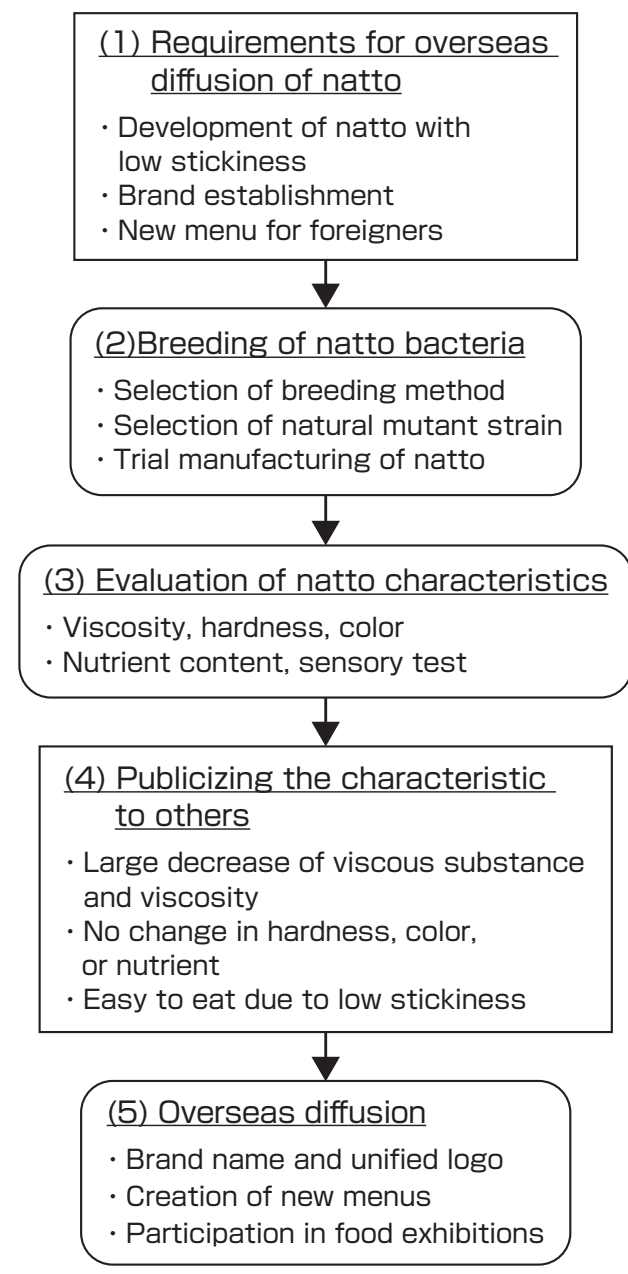

Fig. 1 Scenario for developing natto with low stickiness and its diffusion overseas
Table 1. Conventional method to manufacture natto with low stickiness and method used by lbaraki ITI

\begin{tabular}{|l|l|}
\hline \multirow{3}{*}{$\begin{array}{l}\text { Conventional } \\
\text { method }\end{array}$} & (1) Working on container \\
\cline { 2 - 2 } & (2) Addition of glue \\
\cline { 2 - 2 } & (3) Use of okara as raw ingredient \\
\hline $\begin{array}{l}\text { Method used } \\
\text { by Ibaraki ITI }\end{array}$ & $\begin{array}{l}\text { Use of natto bacteria that was bred } \\
\text { by repeated selection of natural mutant } \\
\text { strain that arose during subculturing } \\
\text { of natto bacteria }\end{array}$ \\
\hline
\end{tabular}

by working on the container ${ }^{[1]}$ involved a totally different manufacturing method compared to regular natto production, and it was difficult to utilize the already existing facilities of the natto companies. Therefore, facility investment cost was an issue. In the method in which a glue is added, ${ }^{[2]}$ there was a problem of needing an additional manufacturing process of introducing the glue, and there was concern about the consumer's attitude toward a natto product that used raw materials other than soybeans and natto bacteria. There is also the method of reducing natto stickiness by using okara rather than soybeans as a raw ingredient, ${ }^{[3]}$ but when this method was used, there was no soybean in the raw ingredient and the flavor of natto was lost.

From the above steps, to manufacture natto with low stickiness without additional facility investment, we considered it essential that natto bacteria that could produce natto with low stickiness were bred.

\section{Breeding method for natto bacteria that could produce natto with low stickiness}

The viscous component of natto is mainly composed of a polymer called $\gamma$-polyglutamic acid $(\gamma \text {-PGA })^{[4]}$ in which the amino group and the $\gamma$-carboxyl group of glutamic acid are condensed, and a polymer called levan ${ }^{[5]}$ in which fructose is condensed. Particularly, $\gamma$-PGA contributes to the sticky texture, and we considered selecting a strain with low content of this component.

Regarding bacteria or fungi, not limited to natto bacteria, it is known that sometimes the original trait is not maintained and the phenotype may differ from the parent strain when subculturing is repeated. Therefore, to maintain stability in using microorganisms in food, the original strain must be stored in glycerol stocks, liquid-drying tubes, or others, and in general practice, cell expansion is done from the stock close to the original generation. In our research, we conducted an opposite method. Specifically, in repeating the subculturing of the same strain, we isolated all the strains that we felt had altered appearance (that were suspected of natural mutation) compared to the original colony in the culture. Natto was made using all these suspect strains, and the strain from which we were able to create natto with low stickiness was selected (Table 1). 
For breeding the natto bacteria, culture generally used for natto bacteria was used, including cultures containing LB, $\mathrm{E} 9{ }^{[6]}$ and soybean powder. In many cases, there was tendency of finding a strain that was different in appearance from the original strain after subculturing about five times. The work process of breeding the natto bacteria with low stickiness is shown in Fig. 2.

As details of the selection method for obtaining the natto bacteria strain with low stickiness are shown in Fig. 2, Miyagino bacteria, which is a commercially-available starter strain, was planted on an agar plate of soybean powder (soybean flour $0.5 \mathrm{~g}$, sodium chloride $0.2 \mathrm{~g}$, glucose $0.1 \mathrm{~g}$, agar $1.5 \mathrm{~g}$, and water $100 \mathrm{ml}$ ) and cultured at $37^{\circ} \mathrm{C}$ for 48 hours. The grown colony was replanted on a new soybean powder agar plate and cultured at $37{ }^{\circ} \mathrm{C}$ for 48 hours. This was repeated five times or more. Replanting was repeated, and the colony grown on a soy powder agar plate was picked, planted on a LB agar plate, and cultured at $37^{\circ} \mathrm{C}$ for 24 hours. The colony that appeared different from the original colony was transferred to a new LB agar plate to conduct pure culture. Natto was made from all strains that were isolated. All the candidate strains that were isolated were coated onto Schaeffer agar plates [Nutrient Broth (Difco Laboratories, Ltd.) $1.2 \mathrm{~g}$, magnesium sulfate heptahydrate $0.025 \mathrm{~g}$, potassium chloride $0.1 \mathrm{~g}$, iron (II) sulfate heptahydrate $0.0278 \mathrm{mg}$, calcium nitrate tetrahydrate $23.6 \mathrm{mg}$, manganese (II) chloride tetrahydrate $0.198 \mathrm{mg}$, agar $1.5 \mathrm{~g}$, and water $100 \mathrm{ml}$, and were cultured at $37^{\circ} \mathrm{C}$ for two days to obtain sporulation. Then, the spores were collected and suspended in sterilized water. After checking the number of bacteria in the adjusted spore suspension, trial manufacture of natto was done.

Manufacturing of natto was done as follows. First, soybeans were soaked in $20{ }^{\circ} \mathrm{C}$ water three times the amount of soybeans for 16 hours, drained, and cooked for $30 \mathrm{~min}$ at 0.18 $\mathrm{MPa}$. Next, natto bacteria spore suspension was sprayed, so the number of aforementioned soybean bacteria will be $10^{3}$ spores per $1 \mathrm{~g}$ cooked soybeans. This was stirred well. A set amount of the mixture was placed in a foam-polystyrene container, and was covered with a polyethylene film with small holes. Next, a fermentation process was done at $39{ }^{\circ} \mathrm{C}$ and humidity of $90 \%$ for 18 hours, and then, cooling was done at $20{ }^{\circ} \mathrm{C}$ and humidity of $50 \%$ for 2 hours. Curing was done at cool storage of $5{ }^{\circ} \mathrm{C}$ for 1 day or more, to obtain natto.

Normally, fermentation is done for about 18 hours, but less sticky natto could be manufactured even when longer fermentation hours were taken. For the natto thus manufactured, coverage of bacteria, hardness of beans, and stickiness were evaluated, and natto bacteria strains with less stickiness compared to conventional natto strains were selected. The selected bacteria strains were subjected to 16S rRNA genetic analysis and a biotin auxotrophy test, and from those results, it was confirmed that the natto bacteria belonged to the Bacillus subtilis group.

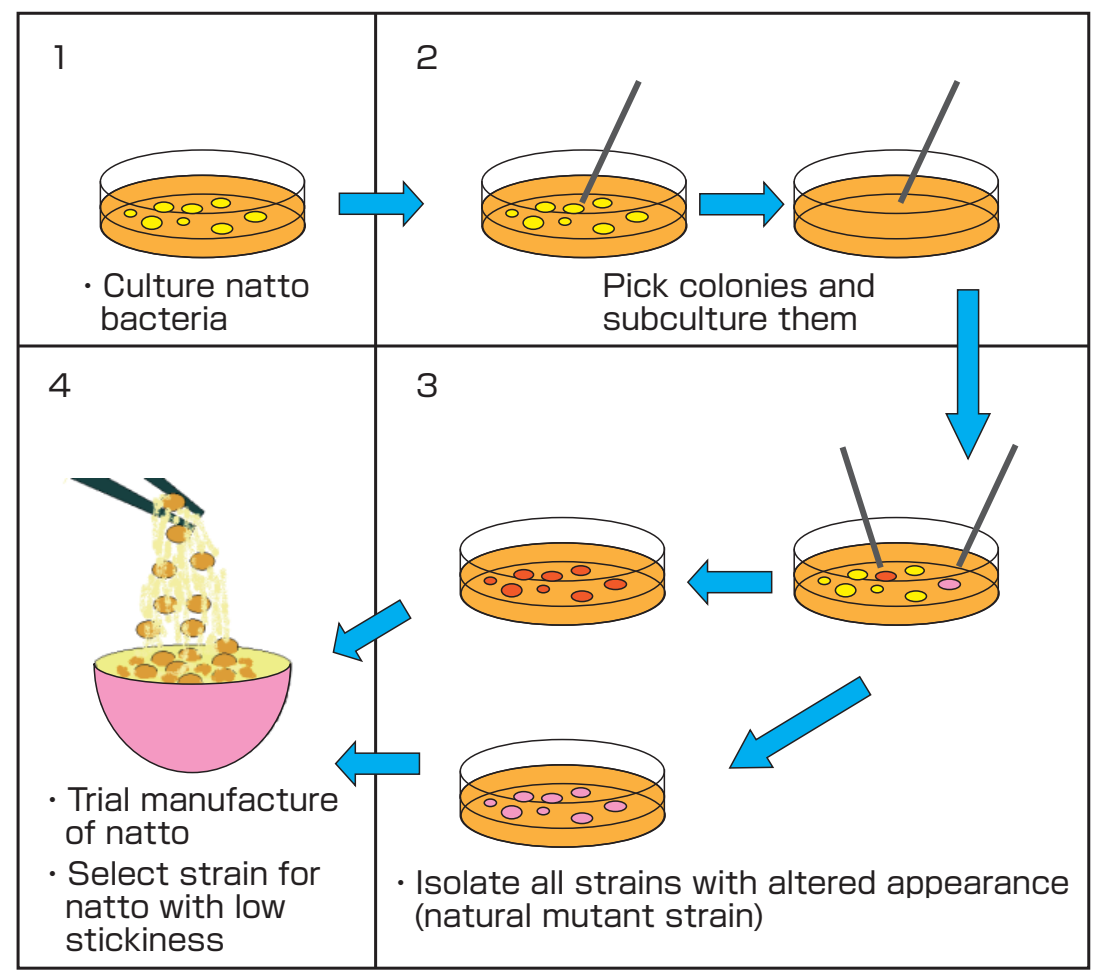

Fig. 2 Breeding method of natto bacteria to manufacture natto with low stickiness 
The difference between natto bacteria and non-nattoproducing Bacillus subtilis is that natto bacteria show biotin auxotrophy and have the ability to produce viscous substances, while non-natto-producing Bacillus subtilis do not show such characteristics.

Since we screened all strains that seemed to have changed appearance, we had about a total of 100-200 strains.

Natto was created from all such strains, and the strains with low stickiness compared to the original strain were confirmed for several strains, but there were variations. Among those, one strain that had particularly low stickiness, excellent mouth-feel, and taste was selected (Fig. 3). This strain was named IBARAKI $\ell$ st-1 and was used for further manufacturing and testing.

\section{Evaluation method for the characteristics of natto with low stickiness manufactured using the IBARAKI est-1 strain}

\subsection{Measurement of viscous substance production in natto}

Natto was manufactured using the IBARAKI $\ell$ st- 1 and Miyagino strains to produce natto that would serve as samples. The natto (about $13 \mathrm{~g}$ ) was weighed and placed in $50 \mathrm{ml}$ centrifugal tubes, and $5 \mathrm{ml}$ of $10 \mathrm{mmol} / \mathrm{L}$ sodium phosphate buffer ( $\mathrm{pH}$ 7.0) containing $1 \mathrm{~mol} / \mathrm{L}$ sodium chloride was added.

After mixing and cleansing the soybean surface, the samples were centrifuged for $5 \mathrm{~min}$ at $8,700 \times \mathrm{g}$ and $4{ }^{\circ} \mathrm{C}$, and the supernatant was batched off into new $50 \mathrm{ml}$ centrifugal tubes. This was repeated three times, and a water-soluble substance was collected. The collected water-soluble substance was centrifuged for $20 \mathrm{~min}$ at $8,700 \times \mathrm{g}$ and $4{ }^{\circ} \mathrm{C}$, and the process of collecting the supernatant was repeated twice. To the 10 $\mathrm{ml}$ supernatant obtained, $25 \mathrm{ml}$ of $99.5 \%$ ethanol was added. This was centrifuged for $10 \mathrm{~min}$ at $8,700 \times \mathrm{g}$ and $4{ }^{\circ} \mathrm{C}$, to collect a viscous substance. The collected viscous substance was dried under reduced pressure, and was weighed. The test was done in three series, average values and standard deviations were calculated, and the values were compared.
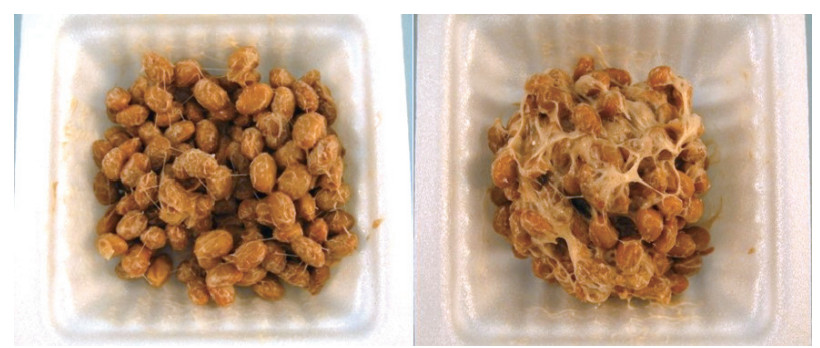

Fig. 3 Natto bacteria with low stickiness (left) and natto made from existing natto bacteria strain (right)

\subsection{Maximum viscosity measurement when natto was stirred}

The Rapid Visco Analyzer RVA-4 (Newport Scientific, Inc.) was used to investigate natto viscosity, and mixing resistance was measured. Since the mixing resistance of natto itself could not be measured since the viscosity was too high, the measurement sample was prepared by adding $1 \mathrm{ml}$ of water to $10 \mathrm{~g}$ of natto. To measure the mixing resistance, the paddle and cup exclusive of RVA-4 were used. The measurement of maximum viscosity was done at 180 rotations per min, sample temperature of $20{ }^{\circ} \mathrm{C}$, and measurement time of 2 min. The measurements were taken in four series, average values and standard deviations were calculated, and the values were compared.

\subsection{Measurement of natto hardness}

The hardness of natto was measured as described in a previously published paper. ${ }^{[7]}$ For about 50 beans of natto, the breaking strength (hardness) in the short-axis direction was measured. Ten beans each with maximum and minimum values were eliminated from the data, and the average values and standard deviations were calculated for the intermediate 30 beans, and this was used as measurement results.

\subsection{Color measurement of natto}

The color of natto was measured using the spectrophotometric color-difference meter SE-2000 (Nippon Denshoku Industries Co., Ltd.). The average values of $\mathrm{L}^{*} \mathrm{a}^{*} \mathrm{~b}^{*}$ measurements of 10 beans were calculated and used as the measurement value. $L^{*}$ represents brightness (value range of 0 to 100 ), and the larger value indicates that it is a bright color. Values for $\mathrm{a}^{*}$ (value range of -60 to +60 ) and $b^{*}$ (value range of -60 to +60 ) represent chromaticity, and higher values of $\mathrm{a}^{*}$ show that red is strong, while higher values of $b^{*}$ show that yellow is strong (Fig. 4).

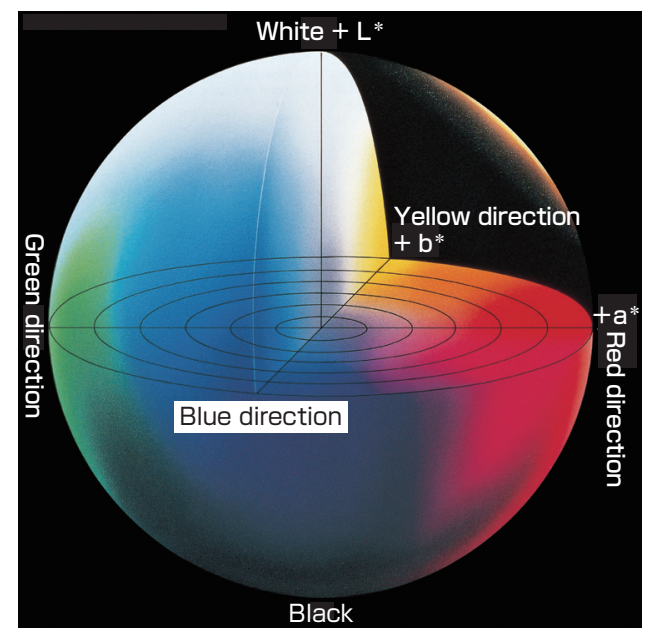

Fig. 4 Relationship between brightness L* and chromaticity $a^{*} b^{*}$

From Iro Iro Zatsugaku, Konica Minolta Japan Inc. 


\subsection{Measurement of contents of basic nutrients, vitamin $K$, and polyamine in natto}

The basic nutrients, vitamin $\mathrm{K}$ that is found abundantly in natto, and polyamines ${ }^{[8][9]}$ (putrecine, spermidine, and spermine) that are drawing attention as natto nutrients were analyzed. The analysis of basic nutrients and vitamin $\mathrm{K}$ were conducted according to previously published papers, ${ }^{[10][11]}$ and the analysis of polyamine was done as follows. Natto was manufactured using the same method as described in Chapter 4, and it was freeze-dried and crushed into powder with a mill. Then $5 \mathrm{ml}$ of $5 \%$ trichloroacetic acid was added to a $1 \mathrm{~g}$ sample, and this was mixed in the vortex mixer. This was centrifuged at $8,700 \times \mathrm{g}$ and $4{ }^{\circ} \mathrm{C}$ for $10 \mathrm{~min}$, and the supernatant was collected. After repeating this process three times, it was diluted in a graduated flask to a $25 \mathrm{ml}$ solution. To $50 \mu \mathrm{l}$ of diluted extract, $50 \mu \mathrm{l}$ of $6 \mathrm{nmol} / \mathrm{ml}$ 1,7-diaminoheptane/0.1 M hydrochloric acid solution, 200 $\mu \mathrm{l}$ of sodium carbonate saturated solution, and $200 \mu \mathrm{l}$ of 10 $\mathrm{mg} / \mathrm{ml}$ dansyl chloride/acetone solution were added. Using a heat block, this was cultured at $70{ }^{\circ} \mathrm{C}$ for $15 \mathrm{~min}$. After adding $25 \mu \mathrm{l}$ of $100 \mathrm{mg} / \mathrm{ml} \mathrm{L}$-proline, this was cultured at $70{ }^{\circ} \mathrm{C}$ for $5 \mathrm{~min}$. After adding $500 \mu \mathrm{l}$ of toluene and mixing well, $500 \mu \mathrm{l}$ of supernatant was extracted. After drying under reduced pressure, this was dissolved in $800 \mu \mathrm{l}$ of acetonitrile, filtered with a $0.45 \mu \mathrm{m}$ membrane filter, and used as the analysis sample. The polyamine analysis was done by highperformance liquid chromatography (HPLC). As a mobile phase, $10 \mathrm{mM}$ ammonium dihydrogenphosphate (liquid A) and acetonitrile (liquid B) were used. Starting from a state in which the ratio of liquid A to B was $45: 55$, the analysis was conducted under a condition where the ratio of liquid B would increase linearly during the analysis time. The flow rate was set at a constant $0.9 \mathrm{ml} / \mathrm{min}$.

The ODS column was used, and the column oven was set at $50{ }^{\circ} \mathrm{C}$. A fluorescence detector was used for detection, and the excitation wavelength was set at $340 \mathrm{~nm}$ and fluorescent wavelength was $515 \mathrm{~nm}$. The polyamine content in the sample was calculated from the calibration curve using the reference standard.

\subsection{Sensory test of natto}

The comparative evaluation of the two types of natto was conducted by 38 healthy males and females, in the 10 s to 60 s age group, without providing any information about the natto. The natto manufactured by the Miyagino strain was set at 3 points (normal) for all evaluation items, and the characteristics and properties of natto manufactured by the IBARAKI $\ell$ st-1 strain were compared and evaluated. Six evaluation items were set, and questions were asked in a multiple choice form for each item of whether natto made from the Miyagino stain was better (stronger), no difference, or natto made from the IBARAKI $\ell$ st-1 was better (stronger).
Table 2. Comparison of viscous substance production (unit: $\mathrm{mg} / \mathrm{g}$ natto)

\begin{tabular}{|c|c|}
\hline IBARAKI $\ell$ st- 1 & Miyagino \\
\hline $11.5 \pm 0.6$ & $15.3 \pm 0.4$ \\
\hline
\end{tabular}

Table 3. Comparison of maximum viscosity when natto is stirred (unit: RVU)

\begin{tabular}{|c|c|}
\hline IBARAKI lst- 1 & Miyagino \\
\hline $201 \pm 49$ & $582 \pm 27$ \\
\hline
\end{tabular}

Table 4. Comparison of natto hardness (unit: $g$ )

\begin{tabular}{|c|c|}
\hline IBARAKI $\ell$ st- 1 & Miyagino \\
\hline $85.2 \pm 8.7$ & $88.9 \pm 9.5$ \\
\hline
\end{tabular}

\section{Evaluation of characteristics of natto with low stickiness and discussion}

\subsection{Comparison of production of viscous substance in natto}

The amounts of viscous substance produced were compared for natto manufactured from the IBARAKI $\ell$ st-1 strain and from the Miyagino strain which is a commercially-available starter strain. As a result, it was shown that with the natto of the IBARAKI $\ell$ st-1 strain, production of viscous substances decreased about $25 \%$ compared to that of the Miyagino strain (Table 2).

From this, it was confirmed that IBARAKI $\ell$ st- 1 was capable of making natto with less stickiness compared to the Miyagino strain.

\subsection{Comparison of maximum viscosity when natto is stirred}

It was found that the maximum viscosity when the natto made from IBARAKI $\ell$ st- 1 was stirred decreased $65 \%$ or more compared to the natto manufactured by the Miyagino strain.

From this, it was indicated that the natto made from IBARAKI $\ell$ st-1 flowed well, and was easier to handle and swallow compared to the natto made from the Miyagino strain (Table 3).

\subsection{Comparison of natto hardness}

The average values of the hardness of natto manufactured by Miyagino and IBARAKI $\ell$ st-1 strains (Table 4) were processed statistically, $\mathrm{t}$ test was done at $\mathrm{P}$ value 0.05 , and the result was 0.119 . Since this value was greater than 0.05 (P value), there was no significant difference in the hardness between the two kinds of natto. Therefore, it was confirmed 
Table 5. Comparison of natto color

\begin{tabular}{|c|r|r|}
\hline Color/natto & IBARAKI lst- 1 & \multicolumn{1}{|c|}{ Miyagino } \\
\hline $\mathrm{L}^{*}$ & 55.14 & 58.97 \\
\hline $\mathrm{a}^{*}$ & 5.49 & 4.55 \\
\hline $\mathrm{b}^{*}$ & 11.90 & 10.32 \\
\hline
\end{tabular}

Table 6. Comparison of basic nutrients of natto (per $100 \mathrm{~g}$ )

\begin{tabular}{|c|c|c|c|c|c|c|}
\hline & $\begin{array}{c}\text { Energy } \\
(\text { Kcal })\end{array}$ & $\begin{array}{c}\text { Moisture } \\
(\mathrm{g})\end{array}$ & $\begin{array}{c}\text { Protein } \\
(\mathrm{g})\end{array}$ & $\begin{array}{c}\text { Fat } \\
(\mathrm{g})\end{array}$ & $\begin{array}{c}\text { Carbohydrate } \\
(\mathrm{g})\end{array}$ & $\begin{array}{c}\text { Ash } \\
(\mathrm{g})\end{array}$ \\
\hline IBARAKI lst-1 & 201 & 58.6 & 16.2 & 9.7 & 13.2 & 2.3 \\
\hline Miyagino & 197 & 59.2 & 16.3 & 9.5 & 12.7 & 2.3 \\
\hline
\end{tabular}

Table 7. Comparison of vitamin $\mathrm{K}$ content in natto (unit: $\mu \mathrm{g} / 100 \mathrm{~g}$ natto)

\begin{tabular}{|c|c|c|c|}
\hline \multirow{2}{*}{$\begin{array}{l}\text { Bacteria species/ } \\
\text { vitamin K type }\end{array}$} & Vitamin $\mathrm{K}_{1}$ & \multicolumn{2}{|c|}{ Vitamin $\mathrm{K}_{2}$} \\
\cline { 2 - 4 } & Phylloquinone & Menaquinone-4 & Menaquinone-7 \\
\hline IBARAKI lst-1 & $22.1 \pm 0.8$ & $3.6 \pm 0.4$ & $1101 \pm 38$ \\
\hline Miyagino & $22.5 \pm 0.2$ & $1.5 \pm 0.0$ & $1027 \pm 14$ \\
\hline
\end{tabular}

from the measurement data that almost the same hardness would be obtained for the natto manufactured using the two strains.

\subsection{Comparison of natto color}

It was shown from the data that the two kinds of natto had almost the same color (Table 5).

\subsection{Comparison of contents of basic nutrients, vitamin $K$, and polyamine in natto}

The analysis results of the basic nutrients, vitamin $\mathrm{K}$, and polyamine in natto are shown in Tables 6-8. It was shown that there were hardly any differences in the basic nutrients and vitamin $\mathrm{K}$ in the nattos manufactured from IBARAKI Łst-1 and Miyagino strains, and there was no nutritional difference between the two. When the natto bacteria is cultured in synthetic culture containing no polyamine at all and the polyamine content in the culture liquid is analyzed, spermine is not detected.

The natto bacteria mainly biosynthesizes spermidine. Looking at the result of Table 8, the spermidine content in the Miyagino strain natto was $30.6 \pm 0.7 \mu \mathrm{g}$ per $1 \mathrm{~g}$ dried natto, while it was $30.6 \pm 0.2 \mu \mathrm{g}$ in IBARAKI $\ell$ st-1 strain natto. As shown in Tables 6-8, in terms of nutritional content of natto, it was shown that the IBARAKI $\ell$ st- 1 strain was not inferior to the Miyagino one, which is the commercially-available starter strain.
Table 8. Comparison of polyamine content in natto (unit: $\mu \mathrm{g} / \mathrm{g}$ dried natto)

\begin{tabular}{|c|c|c|}
\hline $\begin{array}{c}\text { Polyamine type/ } \\
\text { bacteria species }\end{array}$ & $\begin{array}{c}\text { IBARAKI } \\
\text { lst- } 1\end{array}$ & Miyagino \\
\hline Putrescine & $2.4 \pm 0.1$ & $2.4 \pm 0.1$ \\
\hline Spermidine & $30.6 \pm 0.2$ & $30.6 \pm 0.7$ \\
\hline Spermine & $7.9 \pm 0.1$ & $7.3 \pm 0.2$ \\
\hline
\end{tabular}

\subsection{Results of the sensory test for natto}

The evaluation results of natto by a 5-point method and the evaluation results of natto by a multiple choice method are shown in Table 9 and Table 10, respectively. Looking at Table 9, the evaluation of the stickiness item was 3 points for the Miyagino strain natto and 1.47 points for the IBARAKI $\ell$ st-1 one, and it became clear that the difference between the two was recognized.

In the items other than stickiness, excluding the "coverage by bacteria" that indicates the growth of the bacteria, there was no weakness against the Miyagino strain natto and some items had better evaluation. Also, looking at Table 10, pertaining to stickiness, 38 out of 38 people all answered that the Miyagino strain natto was stronger. This means that $100 \%$ of the people felt that the IBARAKI $\ell$ st-1 strain natto had less stickiness, and it was shown that there was a clear difference against the Miyagino one.

For the question, "which is easier to swallow," six people answered that the natto made from the Miyagino strain was easier to swallow, while 24 people or four times that number chose the IBARAKI $\ell$ st-1 strain natto.

For the question, "which was better for care food considering ease of swallowing and handling," 32 out of 38 people answered that the IBARAKI $\ell$ st-1 strain natto was more suitable. From the evaluation results of Table 9 and 10, the 
Table 9. Results of sensory test for natto 1

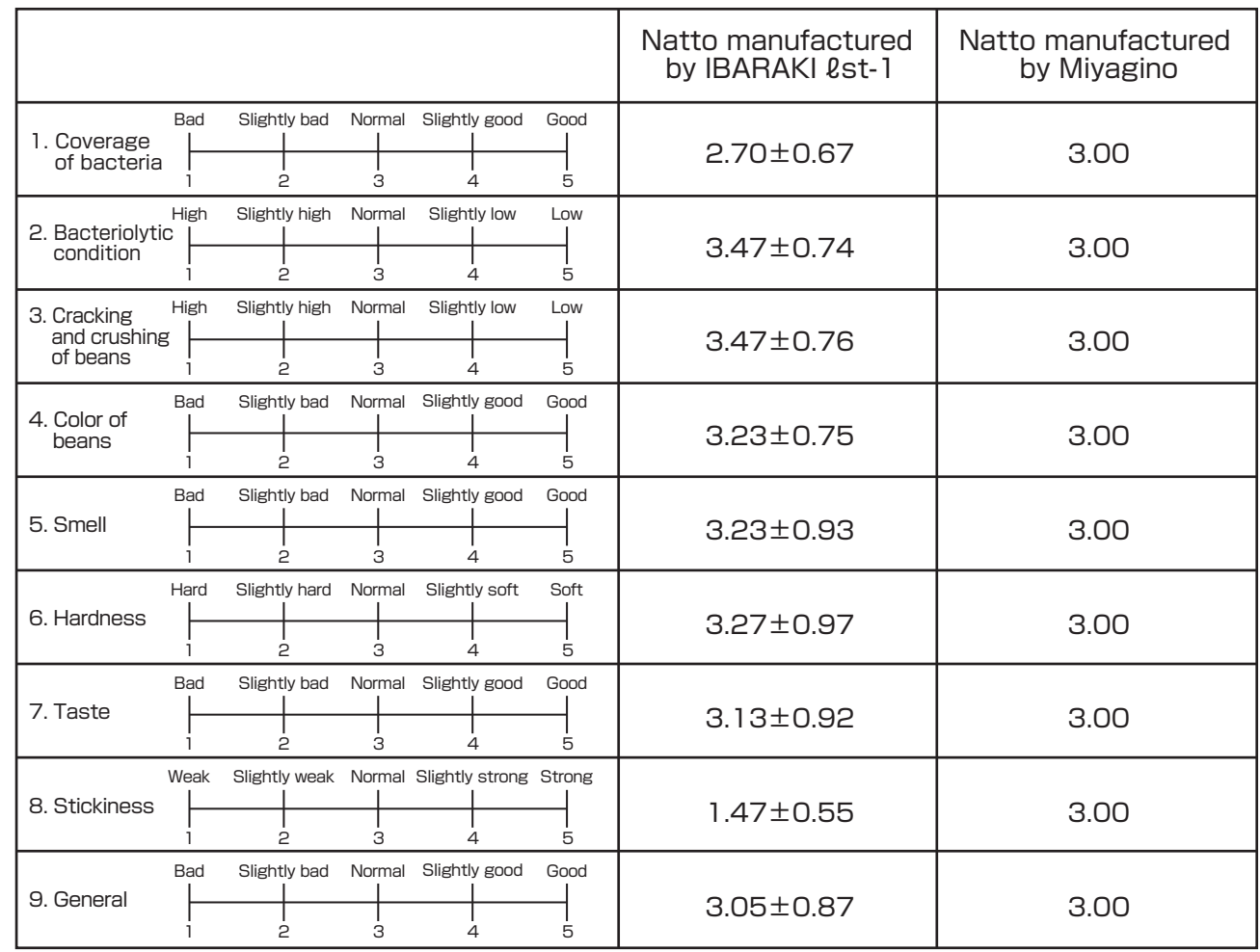

Table 10. Results of sensory test for natto 2

\begin{tabular}{|l|c|c|c|}
\hline & $\begin{array}{c}\text { Natto manufactured } \\
\text { by IBARAKI lst-1 } \\
\text { (no. people) }\end{array}$ & $\begin{array}{c}\text { Natto manufactured } \\
\text { by Miyagino bacteria } \\
\text { (no. people) }\end{array}$ & $\begin{array}{c}\text { No difference } \\
\text { between the two } \\
\text { (no. people) }\end{array}$ \\
\hline \hline Which has better taste? & 13 & 14 & 11 \\
\hline Which has better smell? & 11 & 9 & 18 \\
\hline Which has stronger stickiness? & 0 & 38 & 0 \\
\hline Which is easier to swallow? & 24 & 6 & 8 \\
\hline In general, which is better? & 14 & 16 & 8 \\
\hline Which is better as care food? & 32 & 5 & 1 \\
\hline
\end{tabular}

natto manufactured from the IBARAKI $\ell$ st-1 strain was not inferior to the conventional natto in quality including taste, and differed only in the point that it had low stickiness.

To stably obtain natto with low stickiness even when IBARAKI Łst-1 strain was used repeatedly in natto manufacturing, the original strain was stored by freezing, expansion was done from that strain, and care was taken so that change in quality would not occur through subculturing.

To maintain the low stickiness of natto at the company production sites, it is necessary to pay attention so that there will be no contamination by other natto bacteria within the manufacturing plant.

\section{Development of the research result}

\subsection{Collaboration of industry-academia-government}

Ibaraki ITI called out to the natto companies in Ibaraki that wished to sell the natto made by the IBARAKI $\ell$ st-1 strain to foreign countries, through the Ibaraki Council for the Promotion of Growing Industry.

Specifically, the coordinator of the Tsukuba Center Inc. approached the companies that were interested in product realization of natto with low stickiness, and Ibaraki ITI distributed IBARAKI $\ell$ st-1 to the companies with which agreements were made and provided advice on manufacturing, in collaboration with the Tsukuba Center.

The Industrial Policy Division of Ibaraki prefectural government asked Associate Professor Tadanobu Hara, who was studying 
visual design and package design at the Faculty of Art and Design, the University of Tsukuba, to design the logo. The Division also asked Mr. Hiroshi Fujiwara, a food analyst working as food advisor at the Agriculture, Forestry and Fisheries Project of Ibaraki prefectural government, for advice on the brand strategy. It also asked Mr. Yoshinaga Jinbo, who was the chef and owner of Hatake Aoyama, a restaurant in Tokyo, to develop natto cuisine recipe. Mr. Jinbo was from Hitachi, Ibaraki Prefecture and had studied cooking in France and Italy.

The Industrial Policy Division and Ibaraki ITI built the following industry-academia-government collaboration system, while meeting occasionally to decide on participation in overseas exhibitions and management of intellectual property of natto bacteria that could manufacture lowstickiness natto, as well as on how to carry on the project if there were differences in opinions among the natto companies in Ibaraki (Fig. 5).

Within this industry-academia-government collaboration system, Associate Professor Hara of the University of Tsukuba proposed a unified brand name and logo, "Mamenoka" (Fig. 6). The definition of "Mamenoka" was set as "it must be natto that used IBARAKI $\ell$ st-1."

For use in processed food, Chef Jinbo created menus using Mamenoka (Fig. 7).

\subsection{Participation in food exhibitions in Japan and overseas}

The Ibaraki Council for the Promotion of Growing Industry established the "Mamenoka Project" that is a project for selling the natto manufactured using IBARAKI $\ell$ st- 1 as a new food ingredient, and participated in the following food exhibitions.

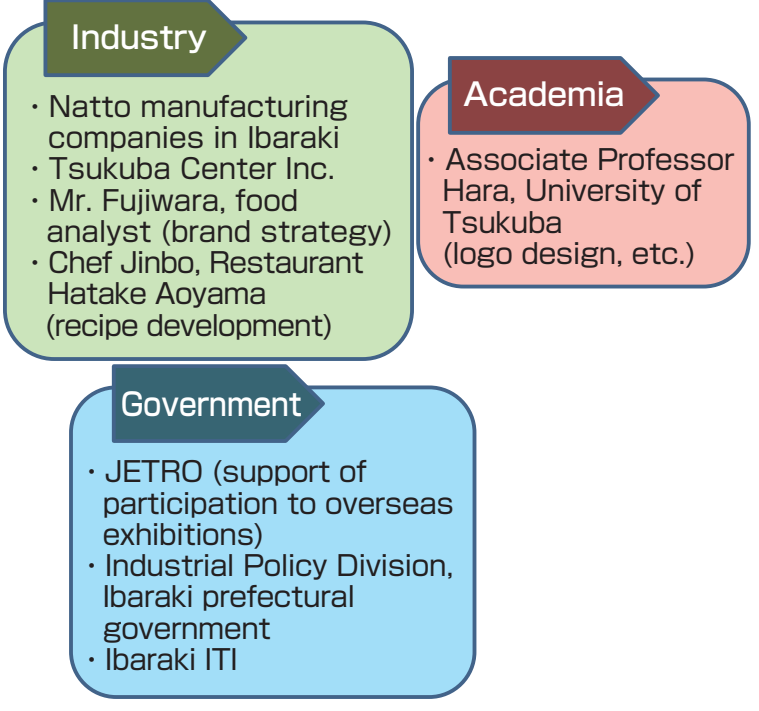

Fig. 5 Collaborative relationship of industry-academiagovernment
(1) Sirha 2015 (Salon International de la Restauration, de 1' Hotellerie et de l'Alimentation)

Held in Lyon, France on January 24-28, 2015 (Fig. 8).

(2) Foodex Japan 2015

Held at Makuhari Messe on March 3-6, 2015 (Fig. 9).

(3) Anuga FoodTec 2015

Held in Koeln, Germany on October 10-14, 2015 (Fig. 10).

(4) Foodex Japan 2016

Held at Makuhari Messe on March 8-11, 2016.

After the exhibitions, some business negotiations are in progress.

While we attended domestic food exhibitions, due to circumstances, we did not go to overseas exhibitions. However, from the stories of the people who participated in the overseas exhibition, the Mamenoka samples were taken very favorably both in France and Germany, and many people of importing companies, restaurant industries, and food manufacturers sampled the product.

However, since foreigners do not have the custom of eating natto with rice like the Japanese, nor do they have the cold chain for natto in food distribution as in Japan, to pioneer

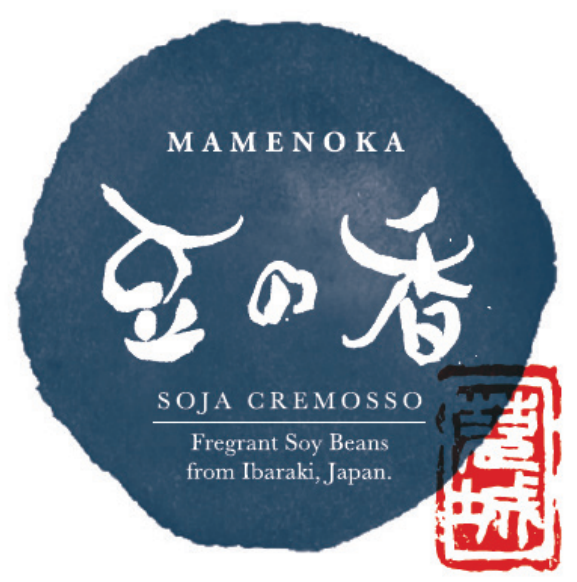

Fig. 6 Unified logo for MAMENOKA

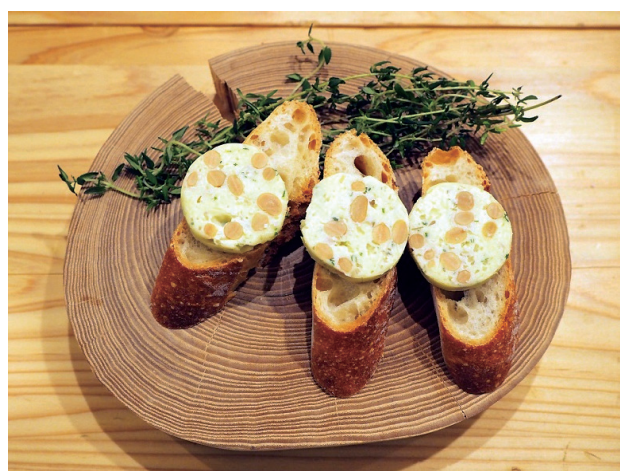

Fig. 7 Example of cuisine using MAMENOKA

Boule de Natto (natto is added to fermented butter, and échalot, wasabi, and konbu powder are used as secret ingredients) 
the overseas sales route for natto, "it is necessary to create new natto products such as dip sauce, paste, or dressing, to propose new ways to eat it, and to develop technologies that allow the natto product to be exposed to room temperature and to lengthen the open date."

Currently, Ibaraki ITI continues to provide technical support to the natto companies in Ibaraki Prefecture. Also, it is working on breeding research for new natto bacteria that allows the extension of the open date of natto products.

\subsection{Intellectual property rights for natto bacteria that can make low stickiness natto}

The natto bacteria that can make natto with low stickiness

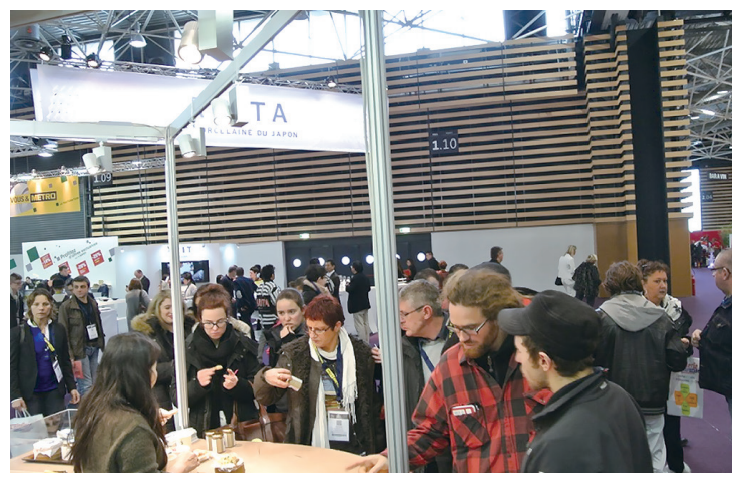

Fig. 8 People visiting the MAMENOKA booth at Sirha 2015

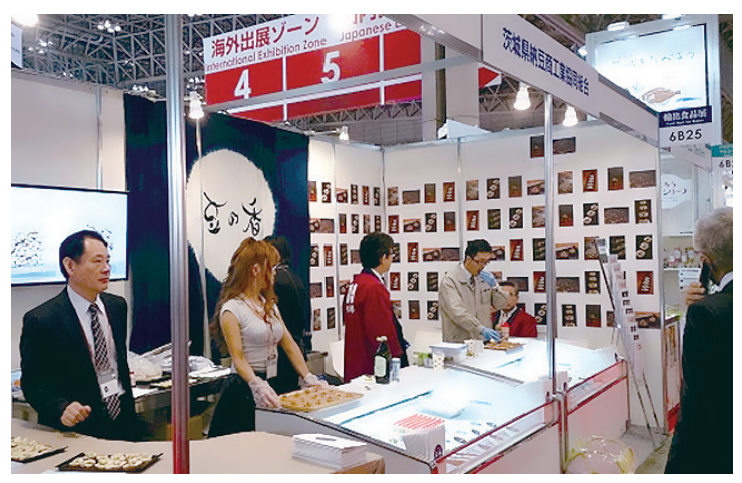

Fig. 9 Exhibition booth at Foodex Japan 2015

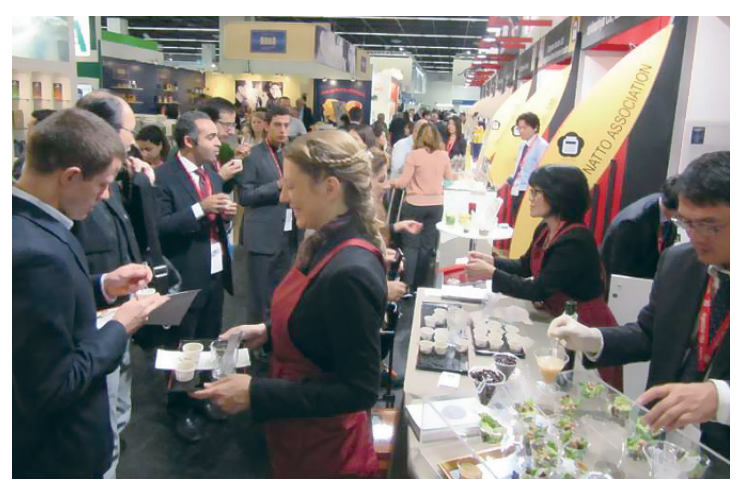

Fig. 10 Sampling of MAMENOKA products at Anuga 2015 was named IBARAKI $\ell$ st-1, and the patent was obtained as "Name of invention: Natto bacteria strain with low stickiness, manufacturing method for natto using this natto bacteria strain, and the natto" (Patent No. 5754009, filed June 5, 2015).

This natto mutant strain was sent to the Patent Microorganism Depository of the National Institute of Technology an Evaluation, under Accession Number NITE P-01836.

IBARAKI $\ell$ st-1 has been provided to six companies in the Ibaraki Prefecture that are participating in the Mamenoka Project, as of August 1, 2017.

\subsection{Mass media coverage of the results}

To publicize the prefectural support of overseas diffusion of natto, the Industrial Policy Division held a natto cuisine tasting event for foreigners living in Ibaraki. Mass media were approached to cover this tasting event, and with the coverage by the Mito Broadcasting Station of Japan Broadcasting Corporation (NHK) that was seeking local news, the Mamenoka project was reported in the news programs of various commercial stations such as TV Tokyo, as well as by NHK Main Station. The Mamenoka project received the Broadcasting Culture Award for the KantoKoshinetsu region from NHK. This is an award for persons (organizations) that contributed to the development of local culture, living, or industry throughout the year in the Kanto-Koshinetsu region, or the persons (organizations) that contributed to various activities of NHK, and it was the first time in four years for an entity of Ibaraki to receive this award. Thus, the Mamenoka project received wide attention and was acclaimed highly in society.

Ibaraki ITI told the mass media reporters, "Please cover the companies manufacturing Mamenoka in the Ibaraki Prefecture, not just ITI," and handed them a "list of companies manufacturing Mamenoka" to help expand the sales route of the Mamenoka product.

Later, some of the Mamenoka manufacturers were covered by the mass media, but the companies were not covered equally, and most of the coverage focused on a certain company only. When the prefectural government and the private companies start up a project in collaboration, the future issue is to obtain understanding and cooperation of the mass media to ensure that they do not focus on a single company only.

\subsection{Product development by companies participating in the Mamenoka project}

As of August 1, 2017, Mamenoka is produced by five companies, Asaichiban Corporation, Kanasago Corporation, Y. K. Kikusui Shokuhin, Y. K. Toko Foods, and Higeta Shokuhin Co., Ltd. The products can be purchased through their websites or at Ibaraki Marché (a shop in Tokyo that sells 
products of Ibaraki Prefecture). The companies differentiated their products from each other through selection of raw material soybeans, manufacture methods, and packaging (Fig. 11).

Due to the low stickiness, Mamenoka has the merit that it can be easily processed such as grinding into paste. Utilizing this merit, the participating members of the Mamenoka project worked on processed products using Mamenoka, and developed dip sauce that could be used for vegetables, waffles in which Mamenoka was kneaded into the dough, Mamenoka paste that could be spread on bread, Mameoka dressing, and others (Fig. 12).

The project members are working on new processed products, and Ibaraki ITI is supporting the development through quality evaluation including bacteria testing.

New processed products are being developed through collaboration with other types of businesses. There is development of gyoza (dumplings) containing Mamenoka at ramen noodle stores, as well as chocolate cakes, madeleines, scones, and others using Mamenoka by confectionery companies. In October 2015, there was a trial of providing dry curry containing Mamenoka as school lunch at Bando City, Ibaraki Prefecture. The use of Mamenoka is spreading to various places.

Although the Mamenoka Project was effective in pioneering the domestic market for natto products by the Ibaraki companies, further administrative support is necessary for the effect to take place in overseas markets. Currently, the

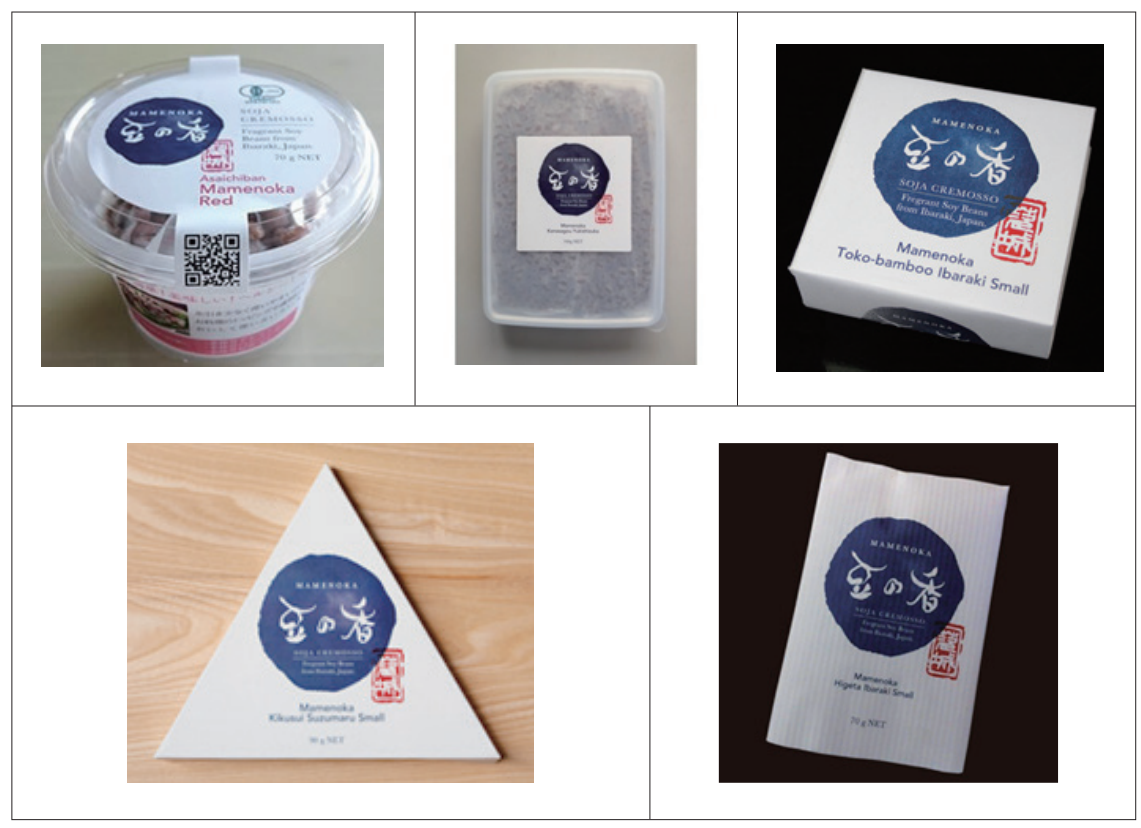

Fig. 11 MAMENOKA from companies participating in the MAMENOKA project From the website pages of MAMENOKA companies
Industrial Policy Division of Ibaraki prefectural government is hiring people of private companies with rich experience in trading overseas. They are stationed in Paris and are approaching the local buyers for products from Ibaraki as well as natto.

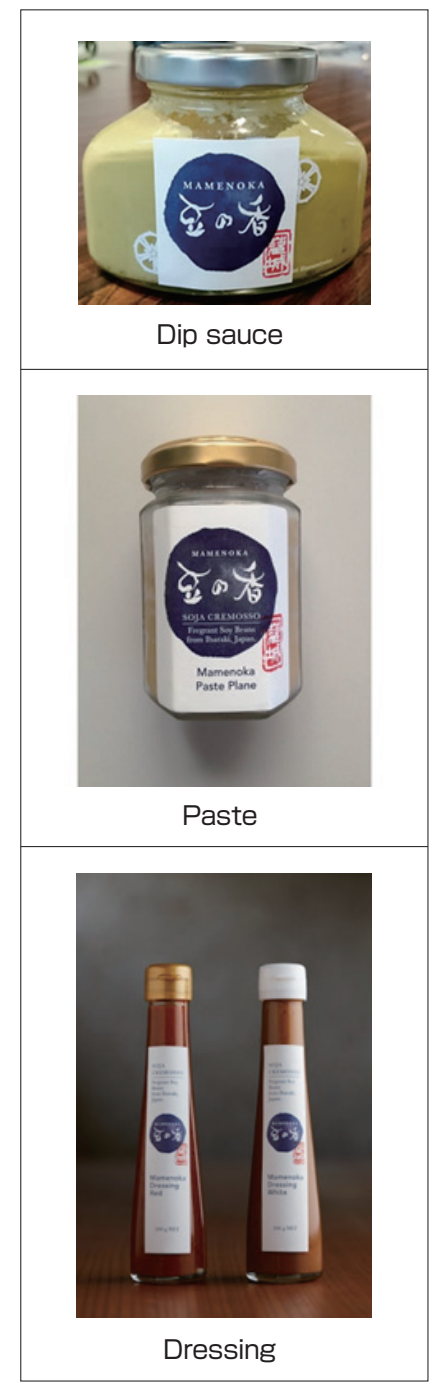

Fig. 12 Examples of processing using MAMENOKA

From the homepages of MAMENOKA companies 


\section{References}

[1] M. Yoshimoto and T. Yoshimoto: Natto no seizo hoho oyobi natto (Manufacturing method of natto and natto), Japanese Unexamined Patent Application Publication No. 2011-92027, application filed 2009.10.27 (2011) (in Japanese).

[2] T. Ota: Natto, Japanese Unexamined Patent Application Publication No. Hei 7-255408 (1995) (in Japanese).

[3] F. Mori: Natto kako shokuhin (Processed natto food), Japanese Unexamined Patent Application Publication No. 2001-128 (2001) (in Japanese).

[4] M. Ashiuchi, C. Nawa, T. Kamei, J. J. Song, S. P. Hong, M. H. Sung, K. Soda and H. Misono: Physiological and biochemical characteristics of poly gamma-glutamate synthetase complex of Bacillus subtilis, Eur. J. Biochem., 268 (20), 5321-5328 (2001).

[5] I. L. Shih, Y. T. Yu, C. J. Shieh and C. Y. Hsieh: Selective production and characterization of levan by Bacillus subtilis (Natto) Takahashi, J. Agric. Food Chem., 53 (21), 8211-8215 (2005).

[6] G. A. Birrer, A. M. Cromwick and R. A. Gross: Gammapoly(glutamic acid) formation by Bacillus licheniformis 9945a: physiological and biochemical studies, Int. J. Biol. Macromol., 16 (5), 265-275 (1994).

[7] Y. Kubo, K. Saito, D. Hohlweck, K. Funane, R. Nakagawa and K. Kimura: Black soybean fermentation using a rpoB mutant strain of Bacillus subtilis (natto), Nippon Shokuhin Kagaku Kogaku Kaishi, 60 (10), 577-581 (2013) (in Japanese).

[8] K. Soda: Ko-polyamine shoku niyoru honyurui no antiaging (Anti-aging in mammals by high-dose polyamine consumption), Nippon Shokuhin Kagaku Kogaku Kaishi, 61 (12), 607-624 (2014) (in Japanese).

[9] K. Soda: Nutritional components and cancer - On polyamines, fatty acids, and polyphenols, Jomyaku Keicho Eiyo, 26 (5), 1211-1220 (2011) (in Japanese).

[10] K. Yasumoto, A. Yasui, M. Takeuchi and T. Watanabe: Gotei Zoho Nihon Shokuhin Hyojun Seibunhyo Bunseki Manual (Fifth Revision and Supplementations, Japan Food Standard Ingredient Chart and Analysis Manual), Kenpakusha, 9-58 (2006) (in Japanese).

[11] K. Kiuchi: Natto No Kenkyuho (Research Method for Natto), Koseisha Koseikaku, 154-158 (2010) (in Japanese).

\section{Authors}

\section{Yuji Kubo}

Chief, Local Food Division, Industrial Technology Institute of Ibaraki Prefecture (Ibaraki ITI). Graduated from the Faculty of Agriculture, Tohoku University in 2004. Completed the master's program at the Graduate School of Life Sciences, Tohoku University in 2006. Employed as staff (chemistry) of Ibaraki Prefecture in 2006, and was assigned to Ibaraki

ITI. Was in charge of food testing research mainly for natto. Obtained doctor's degree (agriculture; doctoral degree by thesis) at the United Graduate School of Agricultural Science, Tokyo University of Agriculture and Technology in 2014, upon summarizing the research results on natto that was conducted at Ibaraki ITI. Writings include "Chapter 3: Daizu kako shokuhin no kinosei (Functionality of processed soybean product)" in Daizu No Eiyo To Kinosei (Nutrition and Functionality of Soybeans), CMC Publishing, 2014. Received the Broadcasting Culture Award for Kanto-Koshinetsu region, Japan Broadcasting Corporation (NHK), 2016.

\section{Rikio NAKAGAWA}

Director, Local Food Division, Industrial Technology Institute of Ibaraki Prefecture (Ibaraki ITI). Graduated from the Department of Agricultural Chemistry, Faculty of Agriculture, The University of Tokyo in 1986. Employed as staff (chemistry) of Ibaraki Prefecture in 1986, and was assigned as the Food Sanitation Inspector at the Mitsukaido

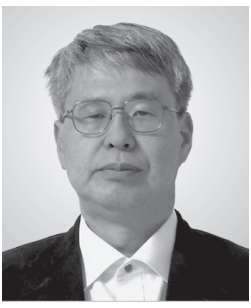
Public Health Center (currently Joso Public Health Center), Ibaraki Prefecture. Was in charge of acreage reduction policy for rice and subsidiaries for soil improvement, at the Agricultural Department of Ibaraki prefectural government from 1988; was in charge of manufacturing dried plums from frozen plums and CA storage test of fruits, etc. at the Distribution Processing Laboratory, Horticultural Research Institute, Ibaraki Agricultural Center from 1993; was in charge of preventing discoloration of lotus roots, comparison of processability into tofu of different soybean species, senbei manufacturing test using low-amylose rice, etc. at the Processed Food Division (current Local Food Division), Ibaraki ITI; Chief Researcher in 2003; Director, Local Food Division in 2007; and also Principal Researcher since 2014.

\section{Discussions with Reviewers}

\section{Overall}

Comment (Keiichi Ikegami, AIST)

This paper discusses the case in which attempt was made for overseas diffusion of natto, a local product, by integration of biotechnology, marketing, and cooking techniques, through wide-ranging collaboration of industry-academia-government personnel. The fact that the products have been actually realized by multiple companies supports the importance for the researchers of public research organizations and the people of industry and academia to share the "scenario" for innovation. I think this is a case study that should be discussed in Synthesiology.

Comment (Noboru Yumoto, National Cerebral and Cardiovascular Center)

This paper describes the process by which natto with low stickiness was developed for overseas diffusion and was made into a brand through the collaboration of industry-academiagovernment. Not being bound by the Japanese custom of natto consumption, there was a clear scenario, and many companies were able to achieve product realization. I think the paper is suitable for publication in Synthesiology.

\section{Clarification of the scenario Comment (Noboru Yumoto)}

For Synthesiology, the requirement of a research paper is the authors' originality of the scenario (the process by which the elemental technologies necessary to achieve the goal were selected and integrated). Although the current manuscript enables the reader to grasp the overall picture, it is slightly difficult to see how the elements were synthesized according to the authors' scenario. Can you create a flowchart of the scenario and clarify how the elemental technologies were synthesized? Also, can you include a description that emphasizes the scenario in your 
abstract?

\section{Answer (Rikio Nakagawa)}

I created a flowchart of the scenario as Fig. 1 to clarify how the elemental technologies were synthesized. For the abstract, I summarized and added the part about "breeding of the natto bacteria" and "evaluation of the characteristics of natto manufactured with the bred natto bacteria," and also changed the description to emphasize the scenario for overseas diffusion.

\section{Building of collaborative relationship \\ Comment (Keiichi Ikegami)}

You mention the building of collaborative relationships among wide-ranging organizations and people. I think such building of organic collaborative relationships is extremely interesting to the readers of Synthesiology. Please add how such collaborative relationships were built and how your "scenario" was shared.

Answer (Rikio Nakagawa)

For the building of collaborative relationships, I added to the text to the extent that can be disclosed.

\section{Subculturing and evaluation of characteristics Question (Noboru Yumoto)}

The natto bacteria you obtained in this research was obtained through repeated subculturing. How do you maintain stability of the bacteria during a repeated use? Also, what was the degree of deviation of the results for the sensory test?

\section{Answer (Rikio Nakagawa)}

For the repeated use of natto bacteria with low stickiness, we ensured that changes in quality did not occur during subculturing by freeze-storing the original strain and expanding from the original. For stability, I added a simple explanation to the paper. For variations in the results of the sensory test, I added the value of sample standard deviation $\left(\sigma_{\mathrm{n}-1}\right)$ in Table 9.

\section{Comment (Keiichi Ikegami)}

Are the people who participated in the sensory test people of the natto industry? Do they like eating natto in the first place? Compared to the general sensory test, I think this is a case where individual preference has major effect on the results, so I would like to know who the testers were.

\section{Answer (Rikio Nakagawa)}

In the stage of natto bacteria breeding research, we had people of the natto companies in Ibaraki do the sensory test. However, the sensory test in Subchapter 5.6 was done by a panel of the following people.

[Sensory test panel]

- Staff of Food Research Institute, National Agriculture and

Food Research Organization

- People of natto companies in Ibaraki Prefecture

- Staff of Industrial Policy Division, Ibaraki prefectural government

- Friends and acquaintances of the authors

We did not question whether the panel members liked or disliked natto. However, the members live in Ibaraki, so I think there was "a mixture of people who like natto and people who are neutral about natto."

\section{Future efforts \\ Comment (Keiichi Ikegami)}

You write about participation in several fairs and exhibitions, but there is diversity in what you call "overseas," and I imagine that there are differences according to countries or ethnicities. What were your impressions from participating in the exhibitions, and how did you feedback the impressions to product development? I think these are points in which the Synthesiology readers will be interested, so please make some additions.

\section{Comment (Noboru Yumoto)}

In the final part, you write, "the use of Mamenoka is spreading to different kinds of food." If you have any activities that you have in mind that are different and unique from what you have been doing, can you explain that to the extent that you can? Particularly, can you describe activities that are necessary to further promote branding and international diffusion that emerged through various discussions at the exhibitions and in making various products?

\section{Answer (Rikio Nakagawa)}

Some of these are business matters and I cannot talk about the details, but I added to Subchapter 7.2 my impressions from the exhibitions, as well as the direction of technical support such as "breeding research of natto bacteria that may extend the open date" that is being conducted by budget from a different project, and to Subchapter 7.5 the efforts of companies to which the technology was provided and our administrative support. 